\title{
CORRESPONDENCE
}

\section{Responsibility in Science}

SIR,--Nature's editorial $(229,513 ; 1971)$ on BSSRS, the British Association, and the problems of science and society ignores one of the crucial differences of approach between the two organizations.

Nature concedes that there is "no harm" in examining the social problems brought about by science, and adds that "there is even a need that public attention should be drawn to some of these issues". This demands, however, more than the occasional attention of a few "sensible" and "sober" individuals. We in BSSRS are concerned with analysing the values of modern science, the relationships of science with society, and the ways in which these relationships can, where necessary, be changed. And unlike Nature, or, apparently, the British Association's council, we do not feel it possible or desirable to divorce the ethical problems of science from the processes of "radicalization of science".

We do not see our role, as Nature seems to, as that of an "enlightened pressure group". To present packaged solutions to complex social problems is the type of élitist decision-making we are trying to avoid; instead of conventional minority pressure group politics, we are concerned to create a climate in which socially irresponsible decisions are confronted by an informed and active public opinion.

We offer proposals for policy where these are relevant, and have already done so over CS, herbicides, sponsored research in universities, and the dumping of radioactive waste. But this is secondary to the main task, that of analysis and criticism through which we can mobilize the social conscience both of the scientific community and of society in general.

Yours faithfully,
PeTER CHAPMAN
DAVID DICKSON
SHIVAJI LAL
JERRY RAVETZ
HILARY ROSE
STEVEN ROSE
JONATHAN ROSENHEAD
DAVID WIELD
MAURICE WILKINS

British Society for Social

Responsibility in Science, 70 Great Russell Street, London WC1

\section{Announcements}

\section{Miscellaneous}

THE inaugural meeting of the Lysosome Club was held on January 23, 1971, and Dr A. Allison, Dr J. Dingle, Professor T. Slater, Dr L. Bitensky and Dr S. F. Contractor were elected to the committee for 1971.

The aims of the Club are to bring together informally scientists working in the field two or three times a year, with one meeting in London and others in the provinces. Any scientist working in this field who would like to join in the activities of the Club should write to the honorary secretary, Dr S. F. Contractor, Charing Cross Hospital Medical School, 62 Chandos Place, London, WC2, enclosing the membership fee of $£ 0.50$.

ERRATUM. Due to an administrative error the penultimate paragraph was unfortunately omitted from Professor W. S. Bullough's article "The Ageing of Mammals" last week (Nature, 229, 608; 1971). The paragraph was as follows:

"As Comfort has pointed out, the key to the problem of prolonging the active life of man lies in the understanding of the basic mechanism of the ageing process, and the advantage of the present theory is that it is immediately open to an experimental approach. A technique now exists for manipulating the duration of mammalian life in a reproducible manner using only normal physiological means. This opens the way for a study of the causes and consequences of the prolongation of life in laboratory mammals and ultimately in man; it has been the lack of such a technique that has for so long prevented any rational study of the biology of mammalian ageing. It is also obvious that even if the present theory should prove to be wrong, the exploitation of this technique may enable the truth to be reached."

\section{British Diary}

\section{Monday, March 8}

Communication of Objectives-Reconciling the Interests of the Organization and the Engineer (5.30 p.m.) Dr D. Pym, Institution of Electrical Engineers, at Savoy Place, London WC2.

"Ford Commuter"-Electric Urban

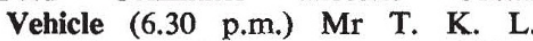
Dobedoe and $\mathrm{Mr}$ R. F. Robbins, Institution of Electrical Engineers, London Graduate and Student Section, at Thames Polytechnic, Wellington Street, London SE18.

Recent Progress on Semiconductor Microwave Sources (2 p.m. colloquium) Institution of Electrical Engineers, at Savoy Place, London WC2.

Tuesday, March 9

Air Conditioning for Human Comfort (7.30 p.m.) Mr J. Bruce, Society of Environmental Engineers, in the Mechanical Engineering Department, The University, Birmingham.
Carbon Black in Coating ApplicationDispersion and Formulation Techniques (7.30 p.m.) Mr L. A. Tysall and Dr D. H. Shearer, Oil and Colour Chemists' Association, at the Griffin Hotel, Boar Lane, Leeds.

Guided Electromagnetic Waves (6.30 p.m.) Professor H. M. Barlow, FRS, Institution of Electronic and Radio Engineers, at University College London, Gower Street, London WC1. (Seventh Clerk Maxwell Memorial Lecture.)

Regulation of Enzyme Synthesis by Phytochrome (5.30 p.m.) Professor H. Mohr, University of London, in the Anatomy Theatre, University College London, Gower Street, London WC1.

Richard Owen, First Director of the Museum (6.30 p.m.) Dr M. Rudwick, British Museum (Natural History) and the Victorian Society, in the Lecture Hall, British Museum (Natural History), Cromwell Road, London SW7.

The Anatomy of the Organ of Voice in Some Genera of Anatidae (Aves: Anseriformes), Dr R. W. Warner;
Wild World, Dr J. H. Sparks (special film on deer); The Seals of Macquarie Island (film, CSIRO Australia) (5 p.m.) Zoological Society of London, at the Zoological Gardens, Regent's Park, London NW1.

The Flow of Information in a University (1.20 p.m.) Professor H. Kalmus, University of London, in the Botany Theatre, University College London, Gower Street, London WC1.

Wednesday, March 10

Aspects of Military Defence Communications: Past and Future (5.30 p.m.) Mr J. R. Mills, Institution of Electrical Engineers, at Savoy Place, London WC2.

Chemical Microscopy-The Overlooked Technique $(2.30$ p.m. $)$ Society for Analytical Chemistry, at the University, Birmingham.

Modernization of Shortwave Transmitting Stations (6 p.m.) Mr C. MacKenzie, Institution of Electronic and Radio Engineers, at 9 Bedford Square, London WC1. 